\title{
EFFECTS OF UTERINE HORN OF PREGNANCY ON BIRTH WEIGHTS AND GESTATION LENGTHS OF DAIRY CALVES*
}

\author{
C. J. WILCOX \\ Department of Dairy Science, University of Florida Institute of Food \\ and Agricultural Sciences, Gainesville
}

(Received 19th Fune 1967)

\begin{abstract}
Summary. Uterine horn of pregnancy was determined in Guernsey, Holstein and Jersey cows during 1959 to 1966 so that the effects of horn upon birth weights and gestation lengths of calves could be evaluated. Only single, normal, living births were included, 1082 cases in all. Through least squares analyses, the possible confounding of effects of year, season, sire and sex, and most of their first-order interactions were removed along with the effects of the age of the dam. Differences between horns in adjusted means of birth weight and gestation length were slight and not statistically significant. Sire, sex and season effects were detected, but none of the first-order interactions was significant. Age of dam effects were found to be curvilinear.
\end{abstract}

\section{INTRODUCTION}

Numerous genetic and environmental factors affect birth weights and gestation lengths (Anderson \& Plum, 1965; Anonymous, 1965; Arnold \& Becker, 1953; and others) and their effects have to some degree been quantified. Only a limited amount of information is available on the effects of the horn of pregnancy, however, and that available is not in particular agreement.

The bovine has a bipartite uterus with a single cervix, a distinct but short uterine body, and distinct right and left uterine horns. Births are normally single. Foote, Tyler \& Casida (1959) found that Holstein calves carried in the right uterine horn weighed $1.78 \mathrm{lb}$ more $(P<0.05)$ than those from the left but that gestation lengths did not differ significantly. Foote, Hauser \& Casida (1960) were unable to detect significant differences with a smaller sample of beef calves, Angus and Shorthorns, nor were differences found by Hancock \& Purser (1964) among Ayrshire and Ayrshire-Friesian calves. In a preliminary study, Wilcox \& Staffa (1964) found that weights were slightly but not significantly greater for calves carried in the right horn.

The object of the present investigation was to obtain estimates of the effects of horn of pregnancy on a larger volume of data than had previously been reported, and with greater statistical control of genetic and environmental factors known to be important.

* Florida Agricultural Experiment Stations Journal Series, No. 2705. 


\section{EXPERIMENTAL PROCEDURE}

The horn of pregnancy was determined by rectal examination 40 to 60 days post-service on Jersey, Guernsey and Holstein cows of the Florida Agricultural Experiment Station during the years 1959 to 1966. Data utilized for analyses represented normal, living, single births of 1082 individuals. Estimates of major effects and first-order interactions were obtained by least squares analysis for the two dependent variables, birth weights and gestation lengths, for each of the three breeds.

Besides the effect of horn, the effects of sire, sex, year and season were included in the model along with most of the possible first-order interactions. A solution of the necessary equations was not possible if all interactions were included. The years 1959 to 1966 were divided into two periods, 1959 to 1962 and 1963 to 1966, based on previous findings for Jerseys in the same herd (Roy, 1964; Wilcox \& Staffa, 1964). This work showed that grouping of adjacent years and months could be accomplished without major increases in error variance. Months of the year were divided into two seasons, October to March and April to September. Linear and quadratic terms for the continuous variable, age of dam also were included.

\section{RESULTS}

Results of the covariance analyses for the three breeds were quite similar. In no case did the effects of horn of pregnancy upon birth weights or gestation lengths approach statistical significance. Covariance adjusted means for the right and left uterine horns are presented in Table 1 for each breed. The

TABLE 1

EFFEGT OF HORN OF PREGNANGY UPON BIRTH WEIGHTS AND GESTATION LENGTHS

\begin{tabular}{|c|c|c|c|c|c|c|}
\hline & \multicolumn{6}{|c|}{ Breed } \\
\hline & \multicolumn{2}{|c|}{ Guernsey (198) } & \multicolumn{2}{|c|}{ Holstein $(310)$} & \multicolumn{2}{|c|}{ Fersey (574) } \\
\hline & $\begin{array}{l}\text { Birth } \\
\text { weight } \\
\text { (lb) }\end{array}$ & $\begin{array}{c}\text { Gestation } \\
\text { length } \\
(\text { days })\end{array}$ & $\begin{array}{c}\text { Birth } \\
\text { weight } \\
(\text { lb })\end{array}$ & $\begin{array}{c}\text { Gestation } \\
\text { length } \\
(\text { days })\end{array}$ & $\begin{array}{c}\text { Birth } \\
\text { weight } \\
\text { (lb) }\end{array}$ & $\begin{array}{c}\text { Gestation } \\
\text { length } \\
\text { (days) }\end{array}$ \\
\hline $\begin{array}{l}\text { Right horn } \\
\text { Left horn }\end{array}$ & $\begin{array}{l}71 \cdot 5^{*} \\
71 \cdot 6\end{array}$ & $\begin{array}{l}284 \cdot 6 \\
283 \cdot 9\end{array}$ & $\begin{array}{l}86 \cdot 2 \\
84 \cdot 5\end{array}$ & $\begin{array}{l}278 \cdot 3 \\
277 \cdot 6\end{array}$ & $\begin{array}{l}53 \cdot 6 \\
52 \cdot 9\end{array}$ & $\begin{array}{l}280 \cdot 2 \\
279 \cdot 8\end{array}$ \\
\hline Residual variance $f$ & 78 & 22 & 143 & 61 & 48 & 30 \\
\hline Standard error $\ddagger$ & $1 \cdot 3$ & 0.7 & $1 \cdot 4$ & 0.9 & 0.6 & 0.5 \\
\hline
\end{tabular}

* Covariance adjusted means; differences not statistically significant for any breed or over-all.

$\dagger$ Associated with 152, 255 and 506 degrees of freedom for the three breeds, respectively.

$\ddagger$ Standard error of the difference between adjusted means.

residual variance $(R)$ has been presented rather than the horn by square interaction, which could be used to test horn effects, since the interaction mean square was less than its error $(R)$.

Among the remaining main effects, sire, sex and season were statistically 
significant but none of their first-order interactions. Age of dam had an appreciable curvilinear effect.

\section{DISCUSSION}

All comparable published research concerning horn of pregnancy effects known to the author is shown in Table 2 . Of the four listed, only the value $1.78 \mathrm{lb}$

TABLE 2

SUMMARY OF PUBLISHED RESEARGH

\begin{tabular}{l|l|c|c|c}
\hline \multirow{2}{*}{ Authors } & \multicolumn{1}{|c|}{ Breed } & $\begin{array}{c}\text { No. of } \\
\text { cases }\end{array}$ & $\begin{array}{c}\text { Birth } \\
\text { weight } \\
\text { (lb) }\end{array}$ & $\begin{array}{c}\text { Gestation } \\
\text { length } \\
\text { (days) }\end{array}$ \\
\hline Foote et al. (1959) & Holstein & 536 & +1.78 & -0.7 \\
Foote et al. (1960) & $\begin{array}{l}\text { Angus } \\
\text { Hereford }\end{array}$ & 128 & -0.9 & -1.0 \\
Hancock \& Purser (1964) & $\begin{array}{l}\text { Ayrshireand } \\
\text { Ayrshirex }\end{array}$ & 286 & -0.28 & +0.67 \\
Present study & $\begin{array}{l}\text { Friesian } \\
\text { Guernsey }\end{array}$ & 198 & -0.08 & +0.74 \\
Holstein & 310 & +1.77 & +0.65 \\
Weighted average & Jersey & 574 & +0.76 & +0.37 \\
\hline
\end{tabular}

* Right minus left horn.

birth weight in favour of the right horn was statistically significant. In this research (Foote et al., 1959) the authors correctly tested the horn of pregnancy mean square against an interaction mean square, sire line by horn. However, their interaction mean square of 24 was considerably lower than its own error term of 115. Had the authors used the more conservative test, mean square 115, the apparent difference between horns for birth weight would not have been statistically significant.

Unfortunately one cannot validly combine the results of the various investigations published, although a weighted average for the total 2104 births has been shown. Based on present knowledge and an awareness of the possibility of a Type II error (effect present but not detected), it appears that the effects of horn of pregnancy upon birth weights and gestation lengths are either nonexistent or very small.

\section{ACKNOWLEDGMENTS}

The author wishes to acknowledge the technical assistance of F. C. Neal, K. R. Owens, J. A. Staffa and F. G. Martin.

\section{REFERENCES}

Anderson, H. \& Plum, M. (1965) Gestation length and birth weight in cattle and buffaloes: a review. 7. Dairy Sci. 48, 1224. 
Anonymous (1965) Effect of age, sex of calf, time of year and environment on gestation length. Bibliography E/1496. Prepared by Commonwealth Bureau of Animal Breeding and Genetics, Edinburgh.

Arnold, P. T. D. \& Becker, R. B. (1953) Dairy calves, their development and survival. Bull. Fla agrič. Exp. Stn, 529.

Foote, W. D., Hauser, E. R. \& Casida, L. E. (1960) Effect of uterine horn pregnant, parity of dam and sex of calf on birth weight and gestation length in Angus and Shorthorn cows. J. Anim. Sci. 19,470 .

Foote, W. D., Tyler, W. J. \& CAsida, L. E. (1959) Effect of some genetic and maternal environmental variations on birth weight and gestation length in Holstein cattle. J. Dairy Sci. 42, 305.

Hancock, J. L. \& Purser, A. F. (1964) A note on birth weight and gestation length of calves from left and from right uterine horns. Anim. Prod. 6, 373.

RoY, D. K. (1964) Effects of various non-genetic factors upon birth weights and gestation lengths of $\mathcal{F}$ ersey cattle. Thesis, University of Florida.

Wilcox, C. J. \& Stafra, J. A. (1964) Effects of uterine horn pregnant, age of dam and sex of calf on birth weights and gestation lengths of dairy cattle. $\mathcal{F}$. Dairy Sci. 47, 346. 